\title{
Taphonomic Implications of a Crinoid from Echinoderm-Poor Lithofacies in the Upper Ordovician (Katian: Cincinnatian) of Northern Kentucky
}

JAMES R. THOMKA', Center for Earth and Environmental Science, State University of New York at Plattsburgh, Plattsburgh, NY, USA; THOMAS J. MALGIERI, Alpine Ocean Seismic Survey Inc., Hudson, NJ, USA; KAILYN M. POPOVICH-MARTIN, Department of Geosciences, University of Akron, Akron, OH, USA; and CARLTON E. BRETT, Department of Geology, University of Cincinnati, Cincinnati, OH, USA.

ABSTRACT. Crinoids (Phylum Echinodermata) represent major components of fossil assemblages in the type Cincinnatian (Upper Ordovician: Katian) of the greater Cincinnati Arch region. However, certain shallow marine lithofacies are characterized by a nonexistent to depauperate crinoid fauna, being instead dominated by trilobites, bryozoans, mollusks, and in some layers solenoporid algae? and stromatoporoids. One such setting is represented by the Grant Lake Formation, equivalent to the upper Corryville and Mount Auburn members of the McMillan Formation of Ohio, as exposed south of Flemingsburg, Fleming County, northern Kentucky. Described herein is an articulated crinoid crown (Anomalocrinus?) from this otherwise crinoid-poor interval. This occurrence may reflect either (1) a brief interval where conditions were more amenable to occupation by crinoids, possibly corresponding to a minor flooding surface, or (2) transportation of skeletal remains from nearby, deeper offshore areas that contained crinoids in greater abundance. The second interpretation seems more likely given the absence of in situ attachment structures and rarity of disarticulated column material at the study site. This study illustrates the value of echinoderm remains in paleoenvironmental analysis, the significance of crinoidal material in taphonomic interpretation of Paleozoic argillaceous carbonate deposits, and the sensitivity of crinoid fossils as indicators of allochthony or autochthony.

\section{INTRODUCTION}

Crinoids (Phylum Echinodermata) represent one of the most common and widespread faunal groups in the richly fossiliferous type Cincinnatian (Upper Ordovician: Katian) strata of the greater Cincinnati Arch region (Ausich 1996; Meyer and Davis 2009). Although certain intervals are dominated by crinoid columnals and pluricolumnal segments (Meyer et al. 2002), other lithofacies are characterized by a notable paucity of crinoid skeletal elements. Crinoidpoor deposits_-potentially reflecting elevated turbidity, environmental instability, or unsuitable substrates - comprise much of the upper Grant Lake Formation in southern Ohio and adjacent northcentral Kentucky (Brett et al. 2012, 2018). In these deposits, argillaceous carbonates and interbedded gray shales contain a fauna dominated by trilobites (Isotelus sp. sclerites, pygidia, and hypostomes); small, globular trepostome bryozoans (Cyphotrypa sp.); internal molds of nautiloid cephalopods and

${ }^{1}$ Address correspondence to James R. Thomka, Center for Earth and Environmental Science, 132 Hudson Hall, State University of New York at Plattsburgh, Plattsburgh, NY 12901, USA. Email: jthom059@plattsburgh.edu gastropods; fragments, valves, and articulated specimens of the robust brachiopod Vinlandostrophia sp. var. ponderosa; stromatoporoid colonies; and patchily distributed nodular masses of the red alga? Solenopora. These strata likely represent deposition in water depths of 6 to $18 \mathrm{~m}$ (Brett et al. 2015).

Such an interval in northern Kentucky recently produced an unusually deformed crinoid pluricolumnal (Thomka et al. 2014), prompting focused attempts to locate additional echinoderm material from deposits that typically lack these fossils. New crinoid material collected from an echinoderm-poor lithofacies of the Grant Lake Formation is described herein. This find has significance for interpreting taphonomic and paleoenvironmental processes that relate to the occurrence and preservation of crinoids in Upper Ordovician units that lack echinoderm remains in nearly all exposures.

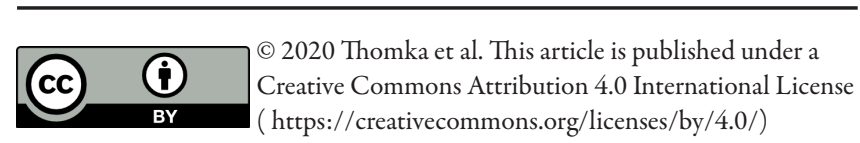




\section{METHODS AND MATERIALS}

The material studied here was recovered from a roadside outcrop on the east side of Kentucky State Route 11 (KY-11), 7.7 km (4.8 mi) south of the metropolitan center of Flemingsburg, Fleming County, northern Kentucky (lat 38 21'22.849"N, long 83 $45^{\prime} 32.382^{\prime \prime W}$ (Fig. 1). This site, in addition to adjacent roadcuts on KY-11, has been included in broader syntheses focusing on lithostratigraphy, sequence and event stratigraphy, and faunal associations in the Cincinnati Arch region (e.g., Weir et al. 1984; Schumacher et al. 1991; Holland and Patzkowsky 2007; Schramm 2011; Malgieri 2015). Upper Ordovician mixed carbonate-siliciclastic strata are exposed, representing the upper portion of the Maysvillian-age Grant Lake Formation and the basal portion of the Richmondian-age Bull Fork Formation (Fig. 2).

The Grant Lake interval is correlative to the upper Corryville and overlying Mount Auburn members of the McMillan Formation (Schramm 2011; Thomka et al. 2014). The lowermost Bull Fork interval, sometimes termed the "Sunset Member," is correlative to the basal Arnheim Formation (Thomka et al. 2014; Malgieri 2015) of adjacent southern Ohio. The upper Corryville-equivalent unit of the Grant Lake Formation is characterized by a rubbly, nodular, texture and carbonate rocks containing a large amount of siliciclastic silt and clay (Fig. 2); this increased detrital input suggests lowered sea levels associated with a falling stage systems tract (Brett et al. 2012; Malgieri 2015). The overlying interval of the Grant Lake Formation (correlative to the Mount Auburn) is sharply set off from the underlying sedimentary rocks. The interval of the Grant Lake equivalent to the Mount Auburn is characterized by more clean carbonates diluted with very little detrital material (Fig. 2), as well as a dense, blocky, texture and fossils showing preservational evidence for prolonged exposure prior to burial; this suggests a transgressive phase and indicates that this unit is separated from the underlying Corryvilleequivalent interval by an erosional sequence boundary. The overlying unit, forming the base of the Bull Fork Formation and correlating to the basal Arnheim, consists predominantly of dark gray shale (Fig. 2), suggesting a slowed rate of transgression transitioning into a highstand phase-allowing increased influx of fine-grained detrital sediment into a low-energy environment.

All stratigraphic units exposed at this locality are notably lacking in echinoderm fossils, including isolated ossicles. Despite the general absence of echinoderms, this site yielded both the single crinoid

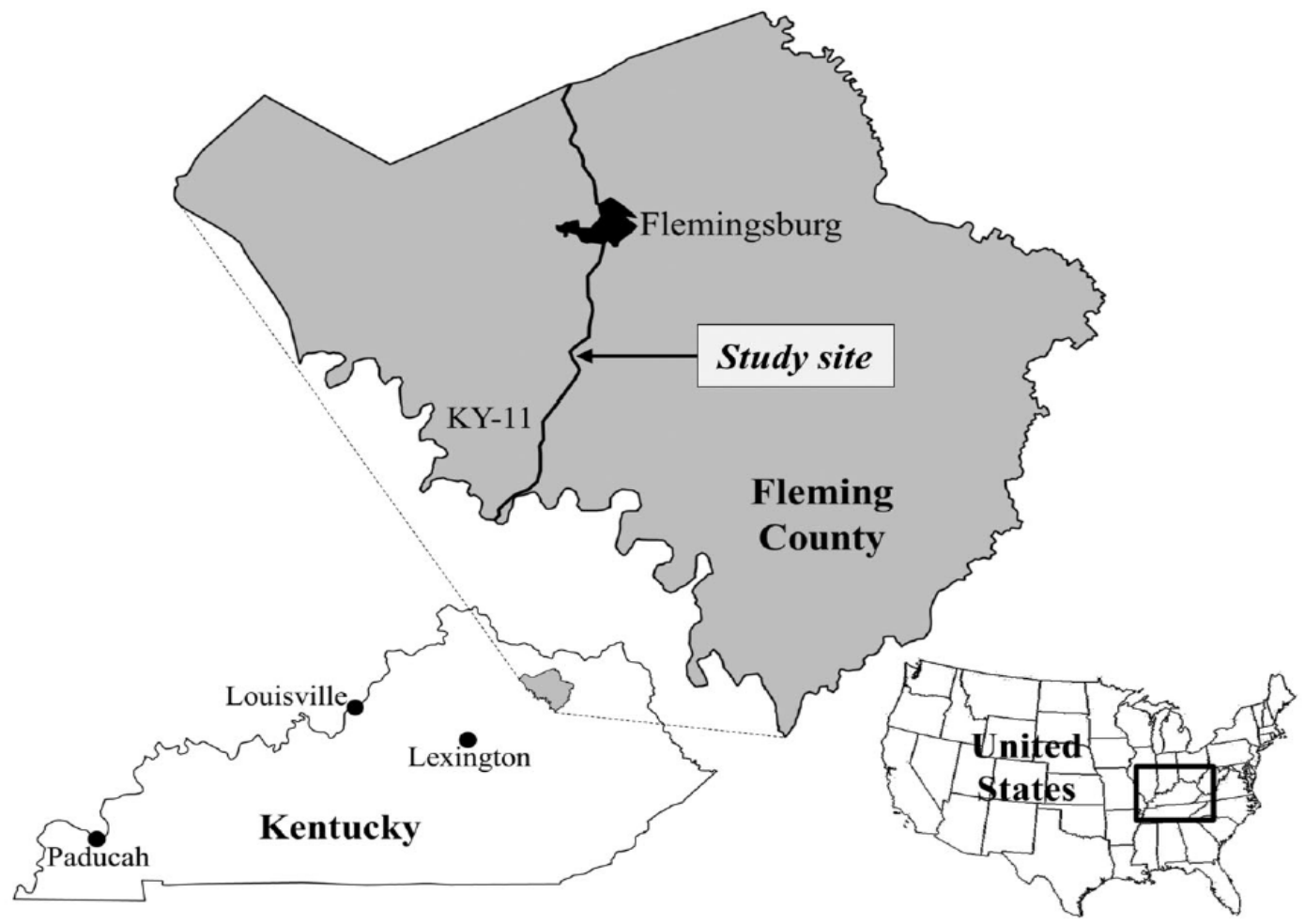

FIGURE 1. Location of the roadside outcrop on KY-11 south of Flemingsburg, northern Kentucky, that yielded the crinoid described in this study. Although no scale bar is present, Fleming County is approximately $29 \mathrm{~km}$ from north to south. Figure from Thomka et al. (2014). 
pluricolumnal described by Thomka et al. (2014) and a subsequently discovered crinoid crown - the latter being the basis of the present study. The fossil is present on the upper bedding plane of an irregular float block (Fig. 3A), the lithological properties of which suggest provenance from the portion of the Grant Lake Formation equivalent to the Mount Auburn Member or potentially the upper Corryville Member (Fig. 2). The slab consists of a bluish-gray argillaceous biomicrite (fossiliferous wackestone) dominated by evenly disseminated trilobite debris (some overgrown by algal laminae), nodular and encrusting algae, and articulate brachiopod (Vinlandostrophia) and ostracod shells and valves. Subordinate elements consist of bryozoansincluding a large, domal, bioeroded zoarium on the upper surface of the bed-and internal molds of mollusks, primarily gastropods (Figs. 3A and 3B). There were no additional visible crinoid fossils on the exterior surfaces of the slab (Fig. 3A). The slab was serially cut perpendicular to bedding to produce multiple polished slabs (a sample polished slab is shown in Fig. 3B). The fabric of the bed was uniform for all slabs and no obvious crinoid elements could be identified (Fig. 3B). A polished surface from the middle of the slab was used to produce a thin section for petrographic analysis (Fig. 3C). The relative uniformity of bed fabric ensured that the thin section was representative of the entire sample, and the location of the slab used to produce the thin section (i.e., from the interior of the middle of the bed) minimized any effects of weathering.

\section{RESULTS}

The specimen described here consists of an articulated crinoid crown with no attached column and some missing distal arm tips (Fig. 4). The cup is slightly damaged, presumably by compaction, and a few calyx plates appear to be missing (preservation grade $\mathrm{M}$ in the classification scheme of Thomka et al. 2011). Details of the cup shape and arm morphology suggest that this specimen is attributable to the aberrant disparid Anomalocrinus, which is known to be present in coeval lithofacies (Brett et al. 2008). Specific features used to aid identification include: the distinctively wide spacing between arm rays; the bulbous, bowl-shaped cup with relatively indistinct sutures; and the pattern of arm branching, which shows characteristics of both pinnulate and ramulate

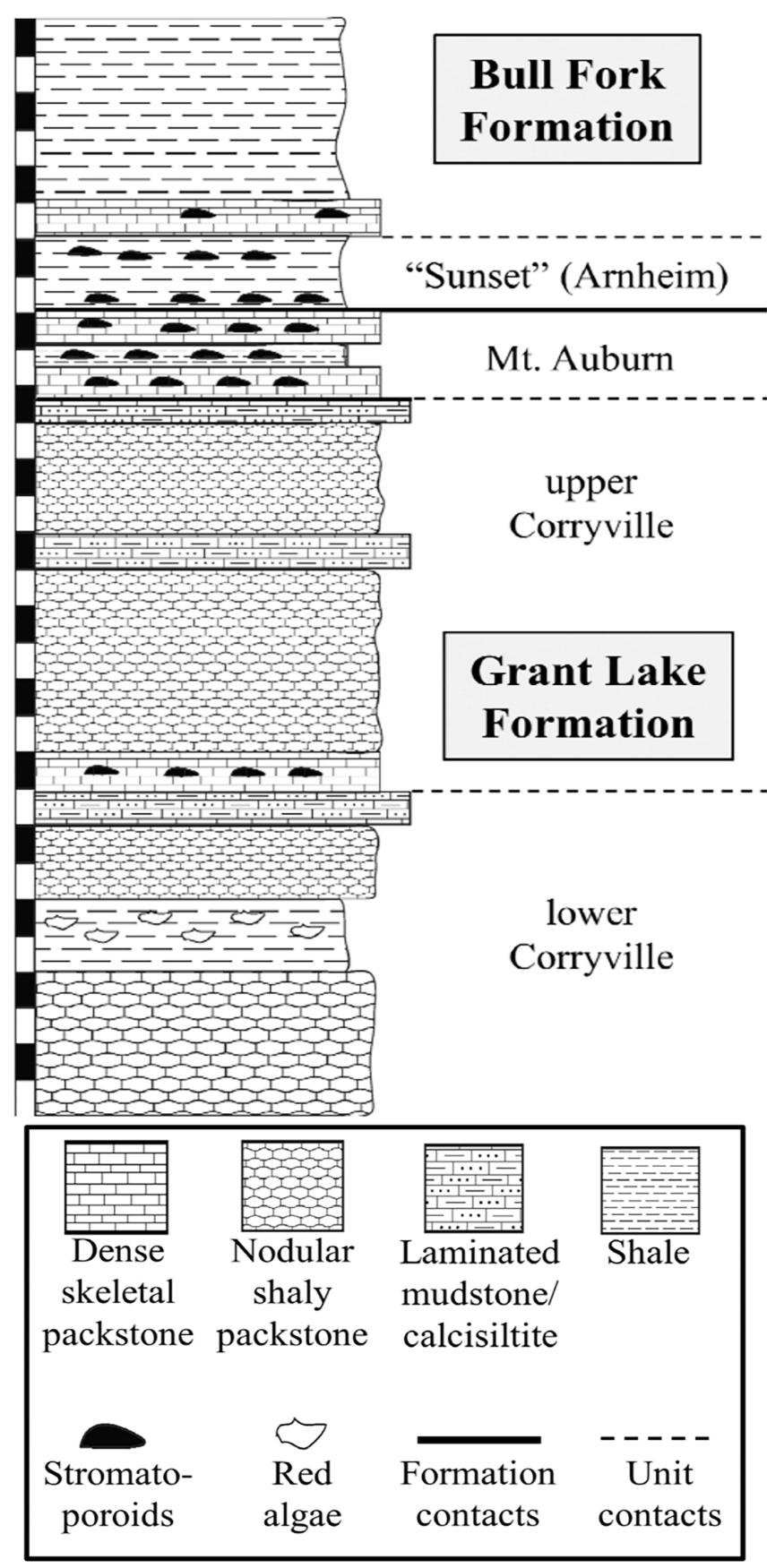

FIGURE 2. Stratigraphy of the units exposed at the study site, with meters marked by the scale bars. Lithostratigraphic nomenclature for formations follows the coarser Kentucky terminology, with component units representing correlative intervals using the more refined lithostratigraphic nomenclature of Ohio. All units exposed at this site are essentially devoid of crinoid fossils. The specimen described in this study was recovered as float, so its precise collection horizon cannot be marked, but the lithologic properties of the slab indicates provenance from the upper Grant Lake Formation, in the unit equivalent to the Mount Auburn or upper Corryville member. Figure modified from Thomka et al. (2014). 

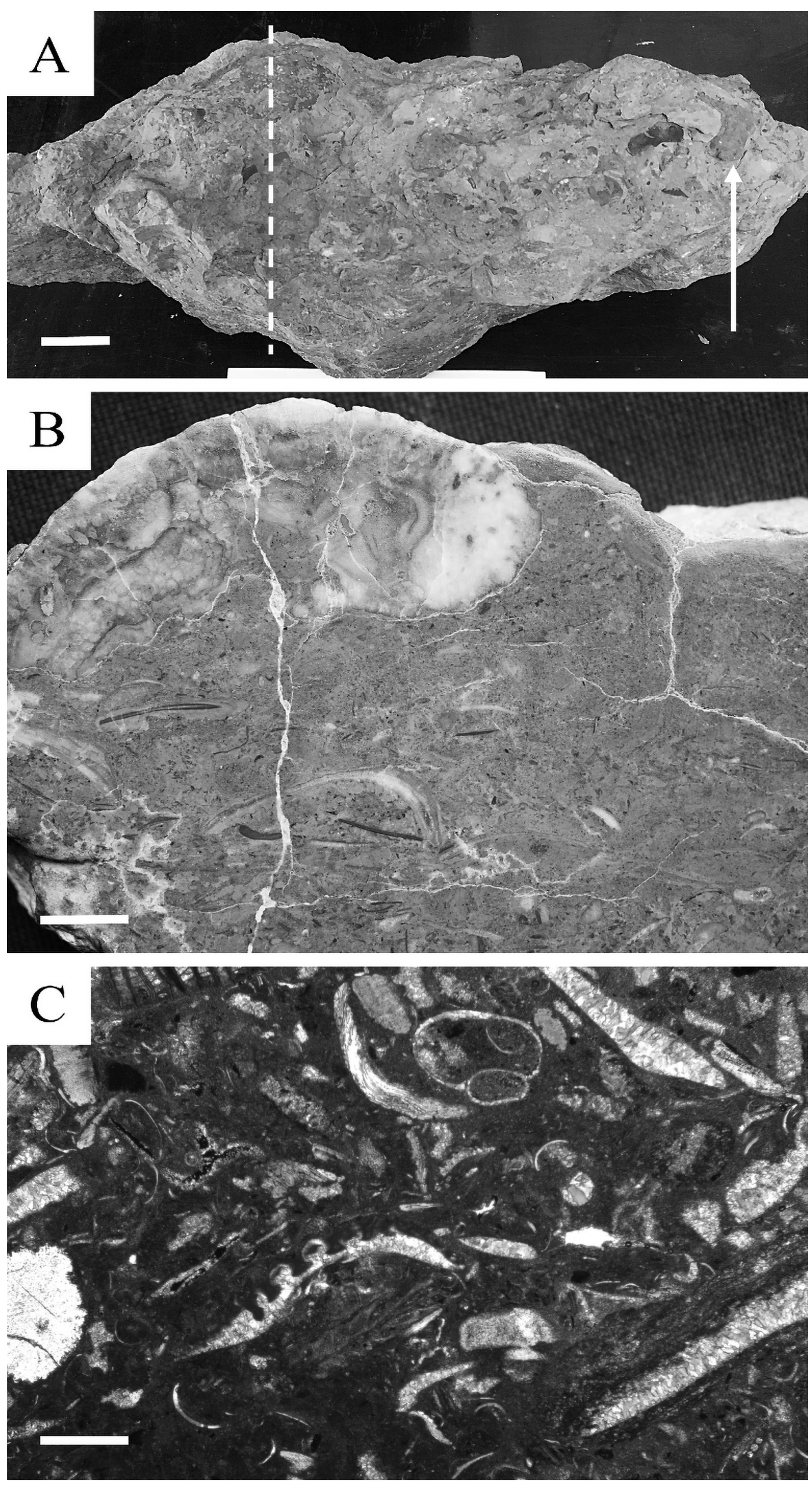

FIGURE 3. Sedimentary aspects of the crinoid-bearing limestone from the upper Corryville-equivalent portion of the Grant Lake Formation at the study site. (A) View of the entire specimen prior to cutting into slabs. Note that the sample is densely fossiliferous, but no echinoderm fossils are visible except for the articulated crinoid crown (marked by arrow, right). The dotted line marks the approximate position of the cross-sectional slice shown in Fig. 3B. Scale bar $=20 \mathrm{~mm}$. (B) Polished slab of the limestone in Fig. 3A showing the texture and composition of the bed. Macroscopic trilobite, articulate brachiopod, bryozoan, and algal material is present. Scale bar $=10 \mathrm{~mm}$. (C) Thin-section microphotograph of the sample shown in crosspolarized light. Note the abundance of articulate brachiopod valves, ostracod valves, ramose bryozoans, and recrystallized (spar-filled) mollusk shells. A small number of putative echinoderm grains are visible. Scale bar $=1 \mathrm{~mm}$. 
morphologies (Fig. 4). Assuming the accuracy of this identification, this represents a relatively small individual-potentially a juvenile. The specimen described here has a crown height of only $23 \mathrm{~mm}$ (Fig. 4), which is smaller than nearly all of the Anomalocrinus crowns recovered from Cincinnatian strata in the collections of the Cincinnati Museum Center (JRT, unpublished data, 2012). It is noteworthy that Anomalocrinus was suggested as a possible identity for the pluricolumnal described from this locality by Thomka et al. (2014). However, given the imperfect preservation of the crown, this identification is herein treated as tentative.

\section{DISCUSSION}

The occurrence of an articulated crinoid crown in a setting typically lacking in crinoids is enigmatic but is best explained by 1 of 2 potential mechanisms. First, the crinoid may have migrated into the depositional environment from an adjacent, more amenable, setting during a brief interval where paleoenvironmental parameters temporarily shifted toward conditions more conducive to occupation by crinoids. Such a change most likely reflects a transgression, associated with decreased turbidity and potentially harder substrates for encrustation. As discussed above, the shift from the Corryville-

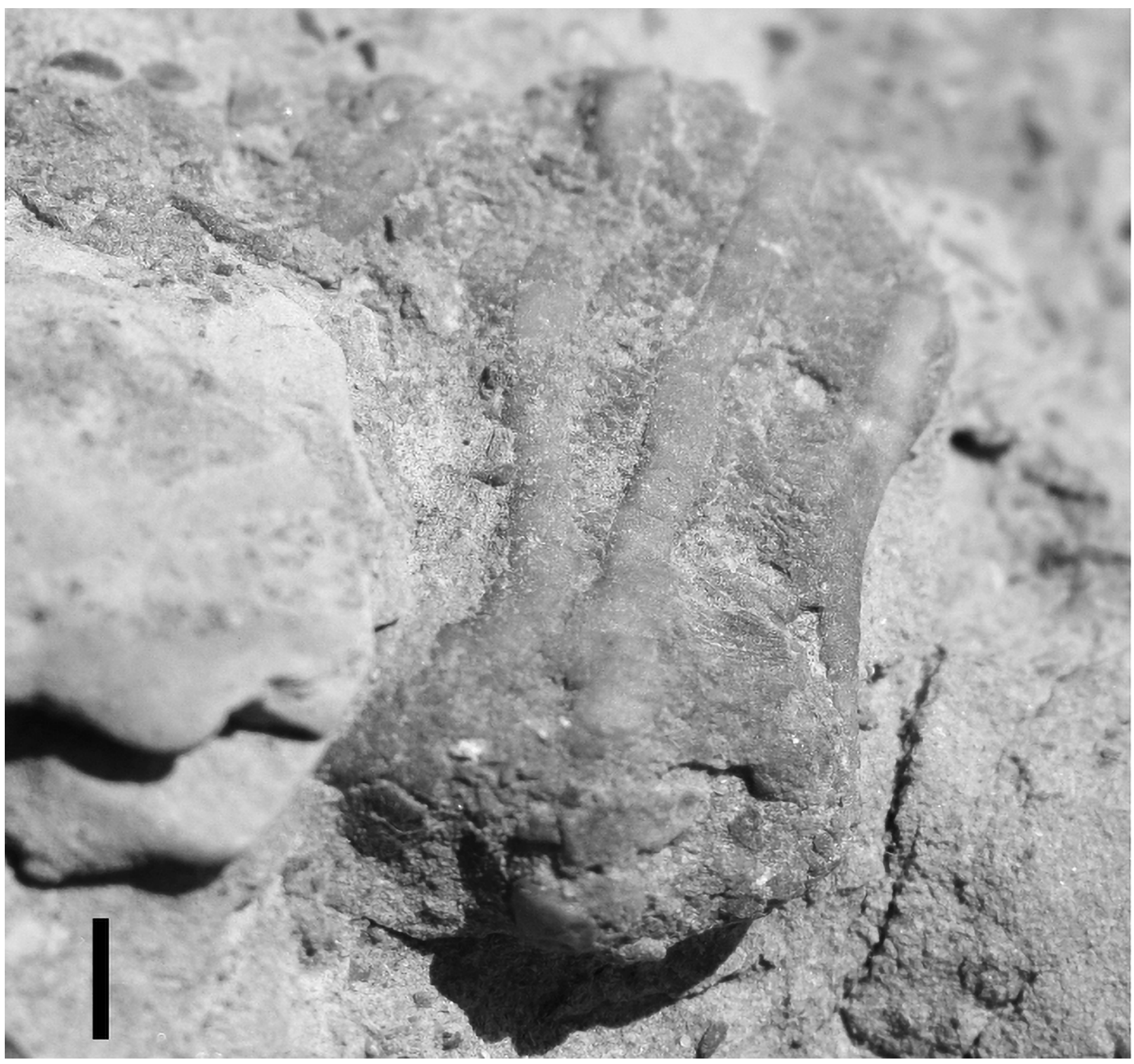

FIGURE 4. Close-up view of the articulated crinoid crown present on the upper surface of the bed shown in Fig. 3A. Note the intact uniserial arms and the wide spacing between rays. This specimen most likely represents a minute (juvenile?) Anomalocrinus, although inferior preservation hinders confident identification. Scale bar $=3 \mathrm{~mm}$ (total crown height $=23 \mathrm{~mm}$ ). 
equivalent portion to the overlying Mount Auburnequivalent portion of the Grant Lake Formation (Fig. 2) would constitute a major transgression. However, internal flooding surfaces within both units (marked by abrupt shifts from argillaceous limestones to stromatoporoid-and Solenopora-bearing horizons) evidently represent minor, higher-order transgressive events (Malgieri 2015). During such phases of relative sea-level change, conditions would have been more amenable for crinoids - which were otherwise restricted to more stable, downramp settings (e.g., Brett et al. 2015). With the transgressive portions of high-frequency sea-level oscillations, crinoids may have expanded from deeper settings into more upramp environments.

Although plausible, this first interpretation seems unlikely given the total absence of in situ crinoid attachment structures, which would indisputably indicate an autochthonous echinoderm fauna. If this crown belongs to Anomalocrinus, then the corresponding holdfast is an encrusting, volcano-shaped, discoidal structure encrusted to hardgrounds and large bioclasts (Brett et al. 2008); no such structures were found attached to stromatoporoids or solenoporid algal heads. Additionally, hardground surfaces, if present, were not encrusted by echinoderms at the study site or immediately proximate localities. Finally, crowns are considerably rarer than elements of the column in Cincinnatian strata (Ausich 1996; Meyer et al. 2002; Brett et al. 2008), so a typical un-transported crinoid assemblage would contain a large number of columnals; however, few columnals are present in the bed containing the crown (Fig. 3). Thin-section analysis resulted in discovery of a small number of grains tentatively identified as isolated crinoid ossicles (Fig. 3C); however, the rarity of specimens, their occurrence exclusively as isolated indeterminate plates, and the apparent biostratinomic edgerounding of some grains suggest that these do not reflect a significant population of in situ crinoids and likely represent transported particles (Meyer and Meyer 1986; Llewellyn and Messing 1993).

A more plausible interpretation is that the crown is allochthonous, having been detached from the column and transported into an environment that was not occupied by living crinoids. The articulated state of the crown indicates rapid burial (Donovan
1991; Brett et al. 1997; Ausich 2001, 2016). It is likely that the high-energy event associated with this rapid sedimentation, almost certainly a storm (see review in Meyer and Davis 2009), was also responsible for separation and transportation of the crown. In modern storm-influenced settings, it is possible for crinoids to be transported to shallow (strandline) environments from depths on the order of 15 to $18 \mathrm{~m}$ (D. L. Meyer, personal communication, 2019); therefore the assumption of storm transport is reasonable. Although physical removal from the column by strong currents seems most likely, it is also possible that the crown was voluntarily detached (autotomized) as a stress response (see Donovan 2012).

Unexpected taxa in atypical environments can potentially have major effects on the detection, analysis, and interpretation of biofacies, particularly in settings where lithologic heterogeneity is minimal and evidence for spatial changes in paleoenvironmental parameters is subtle (Holland et al. 2001; Miller et al. 2001). Further, even at scales more refined than detectable biofacies (i.e., within a single outcrop), lateral spatial variability in faunal composition is an important factor in resolving paleoecological patterns that can be strongly affected by the presence of certain key organisms (e.g., Miller 1988, 1997; Webber 2004). Hence, it is critical to differentiate between taxa that occupied an environment while alive-and therefore provide ecologically meaningful data on organismal distributions - and skeletal remains that were transported into an environment after death. This issue can be mitigated via the use of multivariate statistical gradient analysis of fossil occurrences (Webber 2004, 2005); however, such an approach requires large databases and an existing knowledge of regional faunal gradients.

The current study illustrates the utility of qualitative taphonomic investigation in determination of autochthony vs. allochthony of crinoid fossil material. It is hoped that such considerations are employed in future investigations where atypical or "exotic" taxa can play a role in establishment of quantitatively defined faunal gradients and associations. In such studies, specimens transported post-mortem may contribute to spurious interpretations. 


\section{CONCLUSION}

A crown of the crinoid Anomalocrinus? sp. was discovered from an argillaceous, fossiliferous wackestone (biomicrite) in the Upper Ordovician (Cincinnatian: Maysvillian) Grant Lake Formation near Flemingsburg, northern Kentucky. This occurrence is unusual because this interval is notably lacking in crinoid remains; very few columnals or pluricolumnals are present at this location, and lithologically and geographically similar deposits. Given the lack of in-place crinoid holdfasts on associated substrates and the absence of columnals articulated to the crown, this study suggests that this specimen represents an allochthonous crinoid. A storm event seems the most likely mechanism for displacement and transportation of this individual, as well as for the rapid burial that prevented disarticulation of the crown after settling; however, this remains speculative, as does the precise geographic source of the crinoid. This occurrence highlights the utility of crinoid remains in interpretation of subtle, but often significant, taphonomic processes in Paleozoic deposits.

\section{ACKNOWLEDGEMENTS}

This study was funded by a Dry Dredgers Paleontological Research Award to JRT. Field assistance-and helpful discussions - on Ordovician stratigraphy was provided by Christopher D. Aucoin (University of Cincinnati) and Kyle R. Hartshorn (Dry Dredgers). Caleb W. Holyoke (University of Akron) and Christopher D. Thomas (Drexel University) assisted with preparation and photography of thin sections. An earlier version of this article was significantly improved by reviews provided by Stephen K. Donovan (Naturalis Biodiversity Center), David L. Meyer (University of Cincinnati), and 2 anonymous reviewers. This is a contribution to the International Geoscience Programme (IGCP) Project No. 653: The Onset of the Great Ordovician Biodiversification Event.

\section{LITERATURE CITED}

Ausich WI. 1996. Phylum Echinodermata. In: Feldmann RM, Hackathorn M, editors. Fossils of Ohio. Columbus $(\mathrm{OH})$ : Ohio Department of Natural Resources, Division of Geological Survey. Bulletin 70. p. 242-261.

ISBN-13: 978-0931079054.

http://geosurvey.ohiodnr.gov/publications-maps-data/bulletins

Ausich WI. 2001. Echinoderm taphonomy. In: Jangoux M, Lawrence JM, editors. Echinoderm studies, volume 6. Rotterdam (NL): A. A. Balkema. p. 171-227.

ISBN: HB 9058093018.

Ausich WI. 2016. Fossil species as data: a perspective from echinoderms. In: Allmon WD, Yacobucci MM, editors. Species and speciation in the fossil record. Chicago (IL): University of Chicago Press. p. 301-311.

ISBN-13: 978-0226377445.

https://doi.org/10.7208/chicago/9780226377582.001.0001

Brett CE, Deline BL, McLaughlin PI. 2008. Attachment, facies distribution, and life history strategies in crinoids from the Upper Ordovician of Kentucky. In: Ausich WI, Webster GD, editors. Echinoderm paleobiology. Bloomington (IN): Indiana University Press. p. 23-52.

ISBN-13: 978-0253351289.

Brett CE, Hartshorn KR, Young AL, Schwalbach CE, Stigall AL. 2018. The classic Upper Ordovician stratigraphy and paleontology of the eastern Cincinnati Arch. In: IGCP-653 Field Trip Guidebook. 162 p.

Brett CE, Malgieri TJ, Thomka JR, Aucoin CD, Dattilo BF, Schwalbach CE. 2015. Calibrating water depths of Ordovician communities: lithological and ecological controls on depositional gradients in Upper Ordovician strata of southern Ohio and north-central Kentucky, USA. Est J Earth Sci. 64(1):19-23.

https://doi.org/10.3176/earth.2015.04

Brett CE, McLaughlin PI, Sullivan NB, Thomka JR. 2012. Middle Paleozoic sequence stratigraphy and paleontology of the Cincinnati Arch. In: Brett CE, Cramer BD, Gerke TL, editors. Middle Paleozoic sequence stratigraphy and paleontology of the Cincinnati Arch: part 1 central Kentucky and southern Ohio. IGCP project 591 field trip guidebook. p. 1-54.

Brett CE, Moffat HA, Taylor WL. 1997. Echinoderm taphonomy, taphofacies, and Lagerstätten. In: Waters JA, Maples CG, editors. Geobiology of echinoderms. Cambridge: Cambridge University Press. p. 147-190. Paleontological Society Papers, volume 3. https://doi.org/10.1017/S1089332600000243

Donovan SK. 1991. The taphonomy ofechinoderms: calcareous multi-element skeletons in the marine environment. In: Donovan SK, editor. The Processes of fossilization. New York (NY): Columbia University Press. p. 241-269. ISBN-13: 9780231076746.

Donovan SK. 2012. Was autotomy a pervasive adaptation of the crinoid stalk during the Paleozoic? Geology. 40(10):867-870. https://doi.org/10.1130/G33262.1 
Holland SM, Miller AI, Meyer DL, Dattilo BF. 2001. The detection and importance of subtle biofacies within a single lithofacies: the Upper Ordovician Kope Formation of the Cincinnati, Ohio region. Palaios. 16(3):205-217. https://doi.org/10.1669/0883-1351(2001)016<0205:TDAIOS>2.0.CO;2

Holland SM, Patzkowsky ME. 2007. Gradient ecology of a biotic invasion: biofacies of the type Cincinnatian Series (Upper Ordovician), Cincinnati, Ohio region, USA. Palaios. 22(4):392-407. https://doi.org/10.2110/palo.2006.p06-066r

Llewellyn G, Messing CG. 1993. Compositional and taphonomic variations in modern crinoid-rich sediments from the deep-water margin of a carbonate bank. Palaios. 8(6):554-573. https://doi.org/10.2307/3515032

Malgieri TJ. 2015. Revised sequence stratigraphy and nomenclature of the Ordovician (Katian, MaysvillianLower Richmondian) of southwest Ohio and north central Kentucky [master's thesis]. [Cincinnati $(\mathrm{OH})$ ]: University of Cincinnati. $150 \mathrm{p}$.

Meyer DL, Davis RA. 2009. A sea without fish: life in the Ordovician sea of the Cincinnati region. Bloomington (IN): Indiana University Press. 346 p. ISBN-13: 978-0253351982.

Meyer DL, Meyer KB. 1986. Biostratinomy of recent crinoids (Echinodermata) at Lizard Island, Great Barrier Reef, Australia. Palaios. 1(3):294-302. https://doi.org/10.2307/3514692

Meyer DL, Miller AI, Holland SM, Dattilo BF. 2002. Crinoid distribution and feeding morphology through a depositional sequence: Kope and Fairview formations, Upper Ordovician, Cincinnati Arch region. J Paleontol. 76(4):725-732. https://doi.org/10.1017/S0022336000041986

Miller AI. 1988. Spatial resolution in subfossil molluscan remains: implications for paleobiological analyses. Paleobiology. 14(1):91-103. https://doi.org/10.1017/S0094837300011829

Miller AI. 1997. Counting fossils in a Cincinnatian storm bed: spatial resolution in the fossil record. In: Brett CE, Baird GC, editors. Paleontological events: stratigraphic, ecological, and evolutionary implications. New York (NY): Columbia University Press. p. 57-72.

ISBN-13: 978-0231082501.
Miller AI, Holland SM, Meyer DL, Dattilo BF. 2001. The use of faunal gradient analysis for intraregional correlation and assessment of changes in sea-floor topography in the type Cincinnatian. J Geol. 109(5):603-613. https://doi.org/10.1086/321965

Schramm TJ. 2011. Sequence stratigraphy of the Late Ordovician (Katian), Maysvillian Stage of the Cincinnati Arch, Indiana, Kentucky, and Ohio, U.S.A. [master's thesis]. [Cincinnati $(\mathrm{OH})]$ : University of Cincinnati. $202 \mathrm{p}$.

Schumacher GA, MacSwinford E, Shrake DL. 1991. Lithostratigraphy of the Grant Lake Limestone and Grant Lake Formation (Upper Ordovician) in southwestern Ohio. Ohio J Sci. 91(1):56-68. http://hdl.handle.net/1811/23430

Thomka JR, Lewis RD, Mosher D, Pabian RK, Holterhoff PF. 2011. Genus-level taphonomic variation within cladid crinoids from the Upper Pennsylvanian Barnsdall Formation, northeastern Oklahoma. Palaios. 26(6):377-389. https://doi.org/10.2110/palo.2011.p11-001r

Thomka JR, Malgieri TJ, Brett CE. 2014. A swollen crinoid pluricolumnal from the Upper Ordovician of northern Kentucky, USA: the oldest record of an amorphous paleopathologic response in Crinoidea? Est J Earth Sci. 63(4):317-322. https://doi.org/10.3176/earth.2014.37

Webber AJ. 2004. Methodological advances in the use of faunal gradient analysis for regional high-resolution correlation in the type Cincinnatian Series (Upper Ordovician). Palaeogeogr Palaeocl. 210(2-4):235-248. https://doi.org/10.1016/j.palaeo.2004.02.041

Webber AJ. 2005. The effects of spatial patchiness on the stratigraphic signal of biotic composition (type Cincinnatian Series; Upper Ordovician). Palaios. 20(1):37-50. https://doi.org/10.2110/palo.2004.p04-15

Weir GW, Peterson WL, Swadley WC, Pojeta J. 1984. Lithostratigraphy of Upper Ordovician strata exposed in Kentucky, with a section on biostratigraphy. Reston (VA): United States Geological Survey.. USGS Professional Paper 1151-E:1-121. https://doi.org/10.3133/pp1151E 